\title{
Hayvansal Güdüler: İnsan Psikolojisi Ekonomiyi Nasıl Yönlendirir ve Küresel Kapitalizm için Niçin Önemlidir?*
}

\author{
Animal Spirits: How Human Psychology Drives The Economy and Why It \\ Matters for Global Capitalism
}

\section{Mikail PEHLIVAN ${ }^{1}$ (1)}

\section{öz}

Neoklasik iktisat teorisine göre, ekonomide insan davranışlarına ilişkin kararların rakamlar, istatistikler ve varsayımlar temelinde gerçekleştiği ki, bu varsayımlara dayanılarak alınan rasyonel kararların farklı duygusal koşullar altında da bir değişime uğramadığı ifade edilmektedir. Fakat Amos Tversky ve Daniel Kahneman² tarafından 1974 yılında kısa yollar ve yanlılıklar ile 1979 yılında Beklenti Teorisi'nin ortaya koyulduğu çalışmalarla insanların ancak sınırlı bir rasyonaliteye sahip oldukları ifade edilmiştir. Neoklasik iktisadi varsayımlar ekonomiyi sosyal bir bilim dalı olmaktan uzaklaştııırken davranışsal iktisat ise insanı ekonomiden soyutlamadan ve anlayarak ekonomik olayları açıklamaya çalışmaktadır. Bu çalışmada incelenen, George A. Akerlof ve Robert J. Shiller tarafından yazılan ve 2009 yılında yayımlanan "Hayvansal Güdüler: İnsan Psikolojisi Ekonomiyi Nasıl Yönlendirir ve Küresel Kapitalizm İçin Niçin Önemlidir?" adlı kitap, neoklasik iktisat teorisi dışında bir perspektif ile karar verme sürecinde bireyler üzerinde etkili olan faktörleri ele almaktadır. Iki kısımdan oluşan kitabın, ilk kısmında beş temel güdü (güven, adalet, yolsuzluk, para illüzyonu/yanılsaması ve hikâyeler) açıklanmakta; ikinci kısımda ise, ekonomiyle ilgili sorulan sekiz soruya bu hayvansal güdüler çerçevesinde cevap verilmektedir. Mevcut iktisat teorisinin yapamadığını yaparak ekonomiye hayvansal güdülerin de dahil edilmesi kitabın önemini ortaya koymaktadır. Kitapta, neoklasik iktisat teorisinin varsayımları ve iktisadi

2 Burada adı geçen bilim insanlarının, ifade edilen kavramlara ilişkin çalışmaları için bkz. Tversky, A., \& Kahneman, D. (1974). Judgement Under Uncertainty: Heuritics and Biases. Science, 185(4157), 11241131; Kahneman, D., \& Tversky, A. (1979). Prospect Theory: An Analysis of Desicion Under Risk. Econometrica, 47(2), 263-292.

DOI: 10.26650/JEPR.912647

"Orijinal eserin künyesi: Akerlof, G. A.,\& Shiller, R. J. (2009). Animal Spirits: How Human

Psychology Drives the Economy, and Why It Matters for Global Capitalism, New Jersey: Princeton University Press. Incelenen eserin künyesi: Akerlof, G. A. ve Shiller, R. J. (2018). Hayvansal Güdüler: Insan Psikolojisi Ekonomiyi Nasıl Yönlendirir ve Küresel Kapitalizm İçin Niçin Önemlidir? (Neşenur Domaniç, Levent Konyar, Çev.). İstanbul: Scala Yayıncılık.

'Trakya Üniversitesi, İktisadi ve İdari Bilimler Fakültesi, Maliye Bölümü, Edirne, Türkiye

\section{ORCID: M.P. 0000-0002-7273-333X}

\section{Sorumlu yazar/Corresponding author:}

Mikail PEHLIVAN

Trakya Üniversitesi, İktisadi ve İdari Bilimler Fakültesi, Maliye Bölümü, Edirne, Türkiye

E-posta/E-mail: mikailpehlivann@gmail.com

Başvuru/Submitted: 09.04.2021

Revizyon Talebi/Revision Requested: 13.04.2021

Son Revizyon/Last Revision Received:

14.04.2021

Kabul/Accepted: 26.04 .2021

Atıf/Citation: Pehlivan, M. (2021). Hayvansal güdüler: insan psikolojisi ekonomiyi nasıl yönlendirir ve küresel kapitalizm için niçin önemlidir? iktisat Politikası Araştırmaları Dergisi - Journal of Economic Policy Researches, 8(2), 351-364.

https://doi.org/10.26650/JEPR.912647 
olayları açıklamada kullandığı ekonometri ve istatistik temelli modeller eleştirilirken, yerine davranışsal iktisat teorisi koyulmaktadır.

Anahtar Kelimeler: Hayvansal güdüler, İktisat, Neoklasik iktisat, Davranışsal iktisat, Psikoloji

Jel Sınıflaması: P1, A1, F0

\section{ABSTRACT}

Neoclassical economics states that economic decisions about human behavior are based on figures, statistics, and assumptions, and that rational decisions made on the basis of these assumptions do not change under different emotional conditions. However, as Amos Tversky and Daniel Kahneman stated in their studies in 1974 and Prospect Theory in 1979, people have only limited rationality with heuristics and biases. While neoclassical economic assumptions prevents economics from being a true social science, behavioral economics tries to explain economic events by understanding people without isolating them from economics. The book entitled "Animal Spirits: How Human Psychology Drives the Economy, and Why It Matters for Global Capitalism," written by George A. Akerlof and Robert J. Shiller and published in 2009, deals with the factors affecting individuals in the decision-making process with a perspective other than neoclassical economic theory. In the first section of the two-part book, five basic motives (trust, justice, corruption, money illusion, and stories) are explained, while in the second section, eight questions about the economy are answered within the framework of these animal motivations. The importance of the book is its inclusion of animal motives in the economy that current theory fails to do so. In the book, while the econometric and statisticsbased models used by neoclassical economic theory to explain assumptions and economic phenomena are criticized, behavioral economic theory is put in its place.

Keywords: Animal spirits, Economics, Neoclassical economics, Behavioral economics, Psychology

Jel Classification: P1, A1, F0

\section{EXTENDED ABSTRACT}

Neoclassical economics presumes that future decisions can be made rationally, assuming rational economic agents and complete and costless information in the market. Conversely, this book mentions that there are reactions in economics that cannot be explained by rational thinking, and it makes them explainable with five basic animal spirits. In the first part of the two-part book, five basic motives (i.e., trust, justice, corruption, money illusion, and stories) are explained; in the second part, eight questions about the economy are answered within the framework of these animal motivations. In this evaluation, considering the same plan, firstly, the animal spirits mentioned will be explained, and then the answers given to the questions will be interpreted. While the book is being examined, the examples provided to illustrate the concepts mentioned by the subject are generally not included in the book but were added by the author. 


\section{Part I: Animal spirits}

Trust: Confidence in the economy encourages consumption, investment, employment, and production. On the contrary, if fear prevails in the economy, individuals and companies spend less and save more. This situation causes a decrease in investment and employment.

Justice: At times, the motivation for justice outweighs economic concerns. For example, a worker may choose not to work at all rather than work for compensation that he or she thinks is unfair. The justice motive is so important that even if the economy is in a period of expansion, the source of layoffs can be the unfair economics policies.

Corruption: Bad events that remain in the minds of individuals affect the economy. Remembering these bad events takes the place of fear while removing trust. This situation causes an environment of panic in the economy.

Money illusion: The illusion of money affects many different aspects of the economy, particularly, wage contracts, debt contracts, and accounting transactions. People measure their assets and income according to nominal income rather than real income. The illusion of money stems from a lack of understanding of inflation and deflation.

Stories: The human mind tends to think about stories. Because of story-based human thinking and interaction patterns, telling individuals a story about a particular subject can strongly affect their thoughts on this subject. Stories believed to be true form the basis for economic behavior.

\section{Part II: Eight questions and their connections}

Why do economic recessions happen?: Past stories of economic failure are remembered with the increasing corruption stories before the crisis, which causes the feeling of trust to disappear. Therefore, the belief that economic policies are unfair to people begins to be felt. Later, consumer prices fall, but due to the illusion of money, no one accepts a decrease in their salary, so people become unemployed, and economies begin to shrink.

Why do central bank managers have power over the economy (to the extent that they use it)?: Central banks are the lender of the last resort to which banks may apply for loans. They can mitigate the effects of the crisis by preventing a decline in credit transactions at points at which confidence in the economy decreases. The main task of central banks in implementing such policies is to build confidence in the market. All of these show that animal spirits necessitate the existence of central banks.

Why are there people who cannot find a job?: The reasons for unemployment is partly due to animal spirits such as concerns for fairness, stories and the money illusion. 
Why is there a trade-off between unemployment and inflation?: Animal spirits theory refutes the monetarist theory that there is a natural rate of employment and its claim that people do not have money illusion.

Why don't people consider the future rationally in their decisions about savings?: People have difficulty focusing on the main benefits of savings decisions, namely, how much to save based on animal spirits. In this regard, characteristics such as trust in the economy, environment, age, and culture have an essential role.

Why are asset prices and investment flows so volatile?: Asset prices such as stocks are expected to depend on the basic indicators of companies such as profitability and indebtedness. However, most of the time, the animal motives of the investors come to the fore, and there are price changes in the assets depending on the herd's behavior. Changes in asset prices directly affect people's confidence and the economy.

Why do real estate markets go through cycles?: Increases in real estate prices are mostly based on stories that there is not enough land for the population, and the prices will always increase. If investors believe that they will never find real estate at the current prices, they continue to buy, no matter how much they have risen. In addition, the illusion of money is also an important factor here.

Why does poverty continue across generations among ethnic minorities?: It is stated that in addition to the injustices to which minorities are subjected, their perspective toward themselves also affects the continuity of poverty. Individuals' habit of seeing themselves as a victim of society constitutes the biggest obstacle to self-realization. The perception that nothing will change no matter what leads to a poverty spiral.

In this book, the assumptions of traditional economic theory and the econometrics and statistics-based models used to explain economic events are criticized and replaced with behavioral economic theory. This book, seen as a break from tradition, describes how the economy actually works by doing what current economic theory cannot do. It does this by including animal spirits in the economy.

\section{Giriş}

Neoklasik iktisat, rasyonel iktisadi ajan ve piyasadaki bilgilerin tam ve maliyetsiz oluşu varsayımlarıyla birlikte geleceğe dair kararların rasyonel bir şekilde alınabildiği ön kabulüne sahiptir. Bu kitap ise, ekonomide rasyonel düşünceyle açıklanamayan reaksiyonların olduğundan söz etmekte ve bunları beş temel hayvansal güdü (animal spirit) ile açıklanabilir hale getirmektedir. Yazarlara göre, "hayvansal güdüler” kavramı, "ekonomideki hareketli ve değişken bir unsuru ifade etmektedir. Bizim muğlaklık ve belirsizlikle olan tuhaf ilişkimizi 
ifade etmektedir. Bazen onun yüzünden paralize oluruz. Fakat bazen de bizi tazeler ve enerji kazandırır, korku ve kararsızlıklarımızı yenmemizi sağlar" şeklinde ifade edilmektedir. Bu kitap ile yerleşik makroekonomi teorisinin aksine, hayvansal güdüleri dikkate alan bir makroekonomi teorisi ile gerçekte ekonominin nasıl işlediğine dair bir çerçeve sunulmaktadır. Ayrıca kitapta, yazarların kitap üzerinde çalışmaya başladıkları 2003 tarihi ile kitabın yayımlandığı 2009 tarihi arasında geçen zamanda dünya ekonomisinin ancak hayvansal güdülerle anlaşılabilecek şekilde yöneldiği ifade edilmektedir. Bu bağlamda, Amerika Birleşik Devletleri'nde (ABD) ortaya çıkan ve 2008 yılında küresel nitelik kazanan finans krizine nasıl girildiğinin anlatılması bakımından önem arz etmektedir. Çünkü bu krizin geldiği hemen hemen hiçbir iktisatçı tarafından görülmemiş, hatta birçok kişi krizi ve sonrasında yaşananları gerçekleşmesi imkânsız şeyler olarak görmüştür. ${ }^{1}$

İki kısımdan oluşan kitabın, ilk kısmında beş temel güdü (güven, adalet, yolsuzluk, para illüzyonu/yanılsaması ve hikâyeler) açıklanmakta; ikinci kısımda ise, ekonomiyle ilgili sorulan sekiz soruya bu hayvansal güdüler çerçevesinde cevap verilmektedir. $\mathrm{Bu}$ değerlendirmede de aynı plan gözetilerek, öncelikle bahsedilen hayvansal güdüler açıklanacak, ardından sorulara verilen yanıtlar yorumlanacaktır. Kitap incelenirken, konu itibarıyla bahsedilenleri somutlaştırmak adına verilen örnekler genellikle kitapta olmayıp yazar tarafından eklenmiştir.

\section{I. Kısım: Hayvansal Güdüler}

\subsection{Güven}

Ekonomiye olan güven; tüketimi, yatırımı, istihdamı ve üretimi teşvik etmektedir. Eğer tam aksine, ekonomide korku hâkimse, bireyler ve şirketler daha az harcama yapmakta ve daha çok tasarruf etmektedirler. Bu durum da, yatırımların ve istihdamın azalmasına neden olmaktadır. Dünyanın en başarılı yöneticilerinden biri olarak kabul edilen J. Welch, en başarılı yatırımların içgüdüsel olarak yapıldığını; seçenekler arasında karar verirken rasyonel (mevcut tüm seçeneklerin getireceği sonuçların avantajlarını değerlendirmek ve her birinin olasılığını incelemek) olmaktan çok, "bize, doğru geldiği” için karar vermekte olduğumuzu ifade etmektedir. Hatta, bazı durumlarda tam bilgiye sahip olsak ve rasyonel düşünsek dahi, sırf bize doğru geldiği için o tercihi yaptığımızı belirtmektedir. Bu nedenle ekonomide tüketim, yatırım ve harcama çarpanları gibi "güven çarpanı"” da önemli bir kavram olmaktadır.

\footnotetext{
${ }^{1}$ Nobel ödüllü Richard H. Thaler'in (2019) “Akıllı İnsanların Mantıksız Kararları” adlı kitabında konuyla ilgili ifadesi şu şekildedir: "Bizi konut fiyatlarındaki endişe verici artış hakkında uyaran ekonomist, davranışsal iktisatçı Robert Shiller'd1."

${ }^{2}$ Güven çarpanı, güvende gerçekleşen bir birim değişimin gelirde yarattığı değişimi ifade etmektedir.
} 
Piyasa için güven kavramının ne kadar önemli ve bilinen bir gerçek olduğu, köşe yazarlarının sıkça kullandıkları "piyasalara güven vermek" ifadesinden anlaşılabilir. Enflasyon, istihdam ve borçlanma gibi makro değişkenler için yapılan iyimser beklentiler ve açıklamalar piyasada güven oluşturma amacını da taşımaktadır. Orta Vadeli Program/Yeni Ekonomi Programı ile geleceğe dair iyimser beklentilerin oluşturulmaya çalışılması bu düşünce çerçevesinde ele alınabilir. Bir ülkede bulunan ekonomik büyüme ile iç talep konusunda en önemli göstergelerden biri olan ve tüketicilerin mali durumları, ekonomiye ilişkin değerlendirmeleri ve geleceğe yönelik beklentilerini ifade eden "tüketici güven endeksi" bu konuda somut bir örnektir. Yine buna benzer bir örnek olarak "finansal hizmetler güven endeksi" piyasaların eğilimlerinin belirlenmesinde önemli bir rol oynamaktadir.

Güven kavramını belirsizleştiren en önemli faktörlerden biri neoklasik teoriye göre, piyasa başarısızlığı olarak sayılan asimetrik bilgidir. Asimetrik bilginin giderilmesi ile şeffaf bir yapının oluşması, hem tüketiciler ile üreticiler arasında hem de ekonomide güven duygusunun artmasına neden olacaktır. Bu noktada, Türkiye Cumhuriyeti Hazine ve Maliye Bakanlığı tarafından hazırlanan "vatandaş bütçe rehberi” örnek verilebilir. Bakanlığın ifadesi ile "uygulanacak politikaların sade ve anlaşılabilir dille kamuoyuna açıklanması, mali yönetimin temel ilkelerinden olan şeffaflık ve hesap verebilirliğin sağlanması bakımından büyük önem taşımaktadır” (Hazine ve Maliye Bakanlığ 1,2020 ) şeklindeki tanımlamada bulunan şeffaflık ve hesap verebilirlik kavramlarının güvenle doğrudan ilişkili olduğu unutulmamalıdır. Uluslararası alanda ise borç veren ile borç alan arasındaki güven duygusuyla ilişkili asimetrik bilginin ortadan kaldırılması adına kredi derecelendirme kuruluşları oluşturulmuştur. Burada, ülkelerin risk primleri ile asıl kast edilen ülke piyasalarına olan güvendir.

Diğer yandan, herhangi bir organizasyonun hem iç hem de diş çevresindeki tüm paydaşlara karşı "etik" ve "sorumlu” davranması, bu yönde kararlar alması ve uygulaması şeklinde tanımlanabilecek kurumsal sosyal sorumluluk kavramı; müşteri, tedarikçi, yatırımı, çalışan ve toplum arasında oluşturulacak güven ortamının ekonomiye istikrar getirmesi bakımından önemli bir çalışma alanı olarak karşımıza çıkmaktadır.

\subsection{Adalet}

Bazı zamanlar adalet güdüsü ekonomik kaygılardan daha ağır basmaktadır. Örneğin, bir işçi adil olmadığını düşündüğü bir ücretle çalışmaktansa hiç çalışmamayı tercih edebilir. "Adil ücret teorisi” bu noktada önemli bir kavram olmaktadır. Adalet algısının iki şekilde yansıması bulunmaktadır. Birisi, işçi ile işveren arasındaki ilişkidir. Kendisine adaletli davranılmadığını düşünen işçi, işverene ve kuruma kırılabilir ve daha sonra bu durum işten 
ayrılmasına neden olabilir. Diğer yansıma ise ücretlerle ilgilidir. Çalışan kişi, ücretleri piyasada kendi konumundaki diğer çalışan işçilerin ücretlerine bakarak belirlemektedir. Eğer kendisinin piyasadaki meslektaşlarına göre daha adaletsiz bir ücret aldığını düşünürse, işten çıkabilir, işten kaytarabilir veya işi sabote edebilir. Bu durum, tıpkı gelir düzeyi yüksek olan bireylerin dahi, kendi servetlerini ölçmede diğer bireylerin gelir durumlarına bakarak karar vermesine benzemektedir.

Ekonomide adalet güdüsünün önemli bir yansıması, Orta Vadeli Program'ın amacı ifade edilirken kullanılan “adaletli paylaşıma yönelik ekonomik değişim” vurgusudur. Diğer yandan, sosyal maliyetleri sosyal faydalarını aşan yatırımlar veya yüksek statüye sahip ancak üretken olmayan, korunması yüksek maliyet gerektiren harcamalar olarak ifade edilen “kamusal beyaz filler" in artması toplumda adalet algısında olumsuz bir etki oluşturabilir. Örneğin, kamu kesiminde kullanılan lüks araçlar; ya da üst düzey bürokratların, maaşlarının yanında iki ya da daha fazla yönetim kurulu üyelikleri nedeniyle huzur hakkı adında ek gelir elde etmeleri kamusal beyaz filler olarak görülebilir. Adaletsiz politikaların uygulandığına dair inancın artması sonucu, toplumda adalet algısının bozulması beraberinde piyasalara olan güvenin de ortadan kalkmasına neden olabilir. Sonuç olarak, ekonomi genişleme döneminde olsa bile işten ayrılmaların kaynağı bireylerin adalet algısı olabilmektedir.

\subsection{Yolsuzluk}

Bireylerin aklında kalan kötü olaylar ekonomiyi etkilemektedir. Çünkü bu kötü olayların hatırlanması güveni ortadan kaldırırken yerini korkuya bırakmaktadır. Bu durum ise ekonomide panik ortamının oluşmasına neden olmaktadır. Yolsuzluk, ele alınırken hem bireyler hem de sistem açısından ele alınmalıdır. Bireylerin, muhasebe kayıtlarında, mali tablolarda vb. yaptıkları tahrifler ve değişiklikler somut yolsuzluk davranışlarıdır ve bunların ortaya çıkmasının ekonomide sorun oluşturacağı açıktır. Bunun yanı sıra, sistemin yozlaşması da bir yolsuzluk olarak görülmektedir. Kapitalist sistem, bireylerin beklentilerine/ hayvansal güdülerine göre yöneldiği için yozlaşmaktadır. Bu şekilde yönlenen sistem, bireylerin gerçekten ihtiyaç duymadığı fakat ihtiyaç duyduğunu düşündüğü şeylerin de üretimini sağlamaktadır. 19. yüzyılda ABD'de sahte ilaç patentlerine ayrılan büyük bir sektörün olması, 2008 yılında gerçekleşen mortgage krizi veya Hollanda'da gerçekleşen lale soğanı borsası gibi durumlar buna örnektir.

Bunların yanı sıra, yakın zamanda ortaya çıkan Panama belgelerinde 3 , özel sektör iş çevrelerinden isimlerin bulunması yanında kamu kesiminden de isimlerin olduğu söylenmektedir. Ülkelerin finansal sisteminden paraları süpürüp götüren bu gelişmeler

\footnotetext{
${ }^{3}$ Ambargoları delme, vergi kaçırma ve yasadışı mali hareketleri ortaya çıkaran belgelere verilen ad.
} 
sadece kara para aklama ile sınırlı kalmamakta, hükümetlere olan inanca ve güvene de zarar vermektedir. "Bir mıh bir nalı kurtarır, bir nal bir atı kurtarır” sözünde önemsenmeyen olayların nasıl beklenmedik sonuçlar doğurabildiği vurgulanmaktadır. Başka bir anlatımla, bir çivi eksikliğinden bir nalın düşebileceği, bunun da bir savaşın kaybedilmesine kadar gidebileceği ifade edilmektedir. Yolsuzluk da benzer bir zincirleme etkiye sahiptir.

\subsection{Para İllüzyonu/Yanılsaması}

Para yanılsaması, ekonominin birçok farklı yönünü özellikle de ücret sözleşmelerini, borç sözleşmelerini ve muhasebe işlemlerini etkilemektedir. İnsanlar varlıkları ve gelirlerini reel gelirleri yerine çoğu zaman nominal/parasal gelirleri ile ölçerler. Örneğin, yüksek enflasyon söz konusu olduğunda alım gücünün düşmemesi için nominal maaşların artması talep edilirken, deflasyon ortamında reel gelir sabit kalsa da maaşların düşmesi kabul edilmemektedir. Bu durum şirketlerin işçi çıkartmasına ve dolayısıyla işsizliğin artmasına ve çalışanların daha fazla tasarrufa yönelmesiyle ekonominin durgunluğa girmesine yol açmaktadır.

Para yanılsaması, enflasyon ve deflasyon durumlarının tam olarak kavranamamasından kaynaklanmaktadır. Para yanılsamasına dair başka bir örneğe uluslararası vergi rekabetinde rastlanabilir. Doğrudan yabancı yatırımlar için "verginin sermaye ihraç tarafsızlığ $l^{4}$ " ve "verginin sermaye ithal tarafsızlığ $l^{5}$ " kavramları önemlidir. Bu noktada, yatırımc1 eğer gideceği ülkede uygulanan efektif vergi oranlarına göre değil de yasal vergi oranlarına göre karar verirse nominal değerden hesaplama yaptı̆̆ı için para yanılsaması yaşamış olacaktır.

\subsection{Hikâyeler}

İnsan zihni hikâyeler üzerinde düşünmeye meyillidir. Öykü temelli insan, düşünme ve etkileşim kalıpları nedeniyle, bireylere belli bir konuyla ilgili bir hikâye anlatmanın, bu konudaki düşünceleri üzerinde güçlü bir etkisi olabilmektedir. Doğruluğuna inanılan hikâyeler, ekonomik davranışlara temel oluşturur. Örneğin, 1976 yılında Meksika Başkanı Portillo, petrol rezervleri hakkında yaptığı açıklama ile (200 milyar varil rezerv ile dünyada 2. sırada olduklarını söylemiş fakat daha sonra gerçekte 12,9 milyar varil rezerve sahip oldukları ortaya çıkmıştır) piyasada güven duygusunu oluşturmuş ve altı yıl içerisinde Gayrisafi Yurtiçi Hasıla’nın (GSYH) \%55 artmasına neden olmuştur. Ancak altı yılın sonunda görevinden ayrılırken ülke ciddi bir borç krizi ve işsizlik ile baş başa kalmıştır.

\footnotetext{
${ }^{4}$ Vergilerin, yatırımcıların hangi ülkede yatırım yapacaklarına dair kararlarını etkilememesi durumudur.

${ }^{5}$ Sermaye ithal eden ülkelerin uyguladıkları vergilerin, yatırımcıların yatırım yaptıkları ülkede elde ettiği net getiri haddini, yani vergiden sonraki getiri oranını sermayenin geldiği ülkeye bağlı olarak farklılaştırıcı etki yaratmamasını ifade etmektedir. (Verginin sermaye ihraç ve ithal tarafsızlığı kavramları ile ilgili ayrıntılı bilgi için bkz. (Akkaya, 2011).
} 
Ülkede, petrol rezervleri ile ilgili hikâyeler o kadar etkili olmuştur ki vatandaşlar gerçekleri öğrendikten uzun zaman sonra dahi inanmakta zorluk çekmişlerdir. Bu durum, asimetrik bilgi türlerinden olan ve belli bir amaç uğruna yanlış bilginin kasıtlı bir şekilde kullanılması olarak tanımlanan dezenformasyona benzemektedir. İnsanlara gerçeğin anlatılması yerine inanacakları hikâyelerin anlatılması ekonomiyi etkileyebilmektedir.

Kurgusal da olsa konuyu somutlaştırmak adına, devalüasyon öncesi yerel para birimi cinsinden olan varlıklarını dövize çeviren halk tarafından güvenilen kamu veya özel sektör kurumlarının yöneticileri örnek verilebilir. İlk etapta gerçekleştirilen bu yolsuzluk, daha sonra ekonomi kötü iken akıllara gelecek bir hikâyeye dönüşebilir. Gerçekleştirilecek bir devalüasyonda bu hikâye doğrudan akıllara gelerek, bu işlemin bazı kesimlerin faydasına olduğu inancı ile hükümete ve piyasaya olan güven ve adalet duygularını ortadan kaldırabilir.

\section{II. Kısım: Sekiz Soru ve Bağlantıları}

Hayvansal güdüler ile ekonomik davranışlar arasında önemli bir bağ olduğunu açık bir şekilde ortaya koyan iktisadi sorular şu şekildedir:

\subsection{Ekonomiler Niçin Bunalıma Girer?}

Bunalım öncesi artan yolsuzluk hikâyeleri ile birlikte geçmiş dönemde yaşanan ekonomik başarısızlık hikâyeleri hatırlanmaya başlanır. Bu durum, güven duygusunun ortadan kalkmasına ve böylece, insanlar tarafından ekonomi politikalarının adaletsiz olduğu inancının hissedilmeye başlanmasına neden olur. Daha sonra, tüketici fiyatlarında düşüş gerçekleşir; fakat para yanılsaması nedeniyle kimse maaşında düşüş kabul etmez, dolayısıyla insanlar işsiz kalmaya ve ekonomiler daralmaya başlar. 1890 ve 1930 yıllarında ABD'de yaşanan durgunluk sonucu oluşan finansal panikle birlikte güven duygusunun yitirilmesi ve bankalarda kuyrukların oluşmasıyla gerçekleşen banka krizleri buna örnek teşkil etmektedir.

1 Ocak 1895 y1lında Chicago Daily Tribune gazetesinde yayımlanan yolsuzluk haberleri de hayvansal güdülerden hikâyeler kısmını açıklamaktadır. Ayrıca, bu dönemde işverenler fiyatların düştüğünü görünce işçilerine ücret indirimlerinin zorunlu hale geldiğini söylemişler ve büyük itirazlara rağmen indirimler gerçekleştirilmiştir. Bu indirimlere karşı güçlü direnç gösteren bazı işçiler eski nominal/parasal ücretleriyle ilgili bir adalet anlayışını ve para yanılsamasını yansıtmaktadır. Bu dönemdeki bir gazete haberine göre "Stanford Íplik Fabrikası'nda çalışan iplik işçilerine ücretlerde indirim yapılmasını kabul etmeyi mi yoksa pazartesi günü fabrikanın kapatılmasını mı tercih ettiklerinin sorulacağ bildirilmiştir. Ücretlerinde indirim yapılmasını kabul etmeyen işçiler fabrikanın kapatılmasını tercih etmişlerdir." Burada para yanılsamasının yanı sıra adalet algısıyla ilgili olarak, işçilerin henüz ücret indirimi yapmamış diğer kuruluşlarda işçilere ödenen ücretlerle karşılaştırma yaparak karar verdikleri ifade edilmektedir. 


\subsection{Merkez Bankası Yöneticilerinin Ekonomi Üzerinde Niçin (Kullandıkları Ölçüde) Gücü Vardır?}

Merkez Bankaları, bankaların kredi için başvuracağı son mercidir. Ekonomiye olan güvenin azaldığı noktalarda kredi alıp verme işlemlerinin azalmasının önüne geçerek krizin etkilerini hafifletebilir. ABD Merkez Bankası'nın (FED-Federal Reserve) kuruluş amacı da budur. Araçları ise reeskont kredileri ve açık piyasa işlemleridir. Reeskont kredileri ile bankalara zor zamanlarda kredi verilir ve bankalarda kuyrukların oluşmasıyla gerçekleşecek güven eksikliği ve panik ortamının önüne geçilir. Açık piyasa işlemleri aracılığıyla da piyasa faizine müdahale edilmektedir. Uygulanan bu tür politikalarda Merkez Bankalarının ana görevi piyasada güven oluşturmaktır. Bu durumu, Büyük Buhran (The Great Depression) zamanı Roosevelt şu şekilde ifade etmektedir: "Korkmamız gereken tek şey korkunun kendisidir". Diğer dikkat edilmesi gereken konu ise ekonomiye reeskont kredileri ile müdahale ederken, bireyler tarafindan bu müdahalenin sermayedar kesime para transferi gibi algılanmamasıdır. Aksi takdirde bu durum, insanlar arasında adalet algısında bozulmaya neden olabilir. Tüm bunlar göstermektedir ki hayvansal güdüler, Merkez Bankalarının varlığını zorunlu kılmaktadır.

\subsection{Niçin İş Bulamayan İnsanlar Vardır?}

İş bulamayan kişiler daha düşük maaşla çalışmayı neden kabul etmez? Veya daha düşük vasıf gerektiren işlerde neden çalışmaz? Daha önce de bahsedilen "adil ücret teorisi” bu konuda önemli bir etkendir. Dışarıdaki fırsatlar ne kadar iyi olursa veya işsizlik oranı ne kadar düşük olursa, işçilerin işverenlerinden bekledikleri adil ücret o kadar yüksek olur. Adil ücret teorisinin hakkaniyet kısmı da (işverenin işçiye haksız davranışta bulunması) ücretin sadece bir simge olduğunu ve her şeyi çözmediğini göstermektedir. Diğer bir hayvansal güdü olan hikâyeler ile bağlantısına ise şu şekilde örnek verilebilir: Üniversite mezunu bazı kimselerin işsiz kalması hem adalet hem de hikâyeler güdüsüyle açıklanabilir. Adalet güdüsü adil ücret teorisinin ücretlerle ilgili kısmına dayanmaktadır. Hikâyeler ise, mezuniyet için verilen emeğin sonucunda, ancak mezun olduğu bölümle ilgili bir işte çalışması gerektiğine dair (aileden ve çevreden duyulan) söylemleri açıklamaktadır. Bu durumda, kişi kendi mesleğini yapamadığı gibi bu söylemler neticesinde başka bir alana da yönelmesi mümkün olmamakta ve işsiz kalmaktadır.

\subsection{Enflasyon ile İşsizlik Arasında Niçin Uzun Vadeli Bir Ödünleşme Vardır?}

Yüksek enflasyon göze alınarak kısa vadede işsizlik oranı düşük tutulabilir. Fakat fiyatlar yükselip enflasyon beklentileri de artınca fiyatlar artmaya devam edecektir. Milton Freidman'a göre enflasyonun stabil kalmasını sağlayacak bir doğal işsizlik oranı bulunmaktadır. Fakat kitapta, doğal işsizlik oranı teorisine karşı çıkılmaktadır. Burada, iki 
önemli durum bulunmaktadır. Birincisi, işçi ücretleri her zaman gerçek alacağından fazla ödenmektedir. Zira işverenler durgunlukta dahi ücretlerin düşürülmesini istememektedir. Çünkü bu durum işçilerin adaletsizlik kaygısı ile şirkete bağlılıklarının azalmasına ve ekonominin canlanma döneminde işten ayrılmalarına neden olabilir. Bu durum kaynak israfına neden olmakla birlikte hem işsizliği artırmakta hem de enflasyonun yükselmesine neden olmaktadır.

İkincisi ise, doğal işsizlik oranını etkilemeyeceği düşünülen nakit ücret esnemezliğidir. $\mathrm{Bu}$ çerçevede, laboratuvar ortamında yapılan bir deneyde \%2 olan enflasyon oranı sıfıra indirilirken, işsizlik oranının \%1.5 arttığı görülmüştür. Çünkü işçiler para yanılsaması yaşayarak ücretlerin düşmesini istememektedir. Bunun sonucunda, işçiler \%0.75 daha fazla para kazanmaktadır. Şirketler \%0.75'lik maliyeti karşılamak için işçi çıkarırken, işsizlik $\% 1.5$ artmaktadır. ABD için işsizlik oranında \%1.5'lik bir artış 2.3 milyon kişi demektir ve bu da yılda 400 milyar dolar kayıp anlamına gelmektedir. Bu durumda insanların para yanılsaması yaşamadığını iddia eden doğal işsizlik oranı teorisi çökmektedir.

\subsection{Gelecek İçin Tasarruf Etmek Niçin Bu Kadar Keyfidir?}

Tasarruf etmenin temel faydalarına odaklanmakta zorlanan kişiler ne kadar tasarruf edeceklerine ilişkin kararları hayvansal güdülerine göre vermektedir. Bu konuda, ekonomiye olan güven, çevre, yaş ve kültür gibi özellikler önemli pay sahibidir. Örneğin, ABD’de tasarruflar emeklilikle ilişkilendirildiği için genç birinin tasarruf etmesine tuhaf bakılmaktadır. Çin'de ise daha minimalist bir yaşam kültürü olduğu için tasarruf daha ön planda olmaktadır. Yine başka bir örnek, kredi kartı ile tüketim arasındaki ilişkidir. Çin'de 1.2 milyar insan olmasına rağmen 5 milyon kredi kartı bulunmaktadır. Fakat bu sayı ABD'de 1.3 milyardır. Yine Singapur'da Merkezi Tasarruf Fonu'nun kurulması ile işçi ve işverenlerin, işçi ücretinin \%5'i oranında katkı yapması koşuluyla başlanan tasarruf kampanyası, zamanla Singapur'un tasarrufunu GSYH'nin yarısına kadar ulaştırmasında önemli bir etken olmuştur. Bireysel emekliliğe otomatik katılım da bu çerçevede ele alınabilir.

\subsection{Finansal Araç Fiyatları ve Kurumsal Yatırımlar Niçin Bu Kadar Oynaktır?}

Hisse senedi gibi varlık fiyatlarının, şirketlerin kârlılık, borçluluk gibi temel göstergelerine bağlı olması beklenmektedir. Ancak çoğu zaman yatırımcıların hayvansal güdüleri ön plana çıkmakta ve varlıklarda sürü psikolojisine (herd behavior/bandwagon effect) bağlı fiyat değişimleri yaşanmaktadır. Varlık fiyatlarındaki değişiklikler, insanların güvenini ve ekonomiyi doğrudan etkilemektedir. Sahip olunan varlıklarda değer artış1 olduğunda tüketiciler daha fazla almaya yönelir ve şirket kârları yükselir. Bu durum "aşırı ısınmış ekonomi” ile ifade edilen, piyasaya olan güvenin normal sınırları aştığı yere kadar devam eder ve daha sonra aniden bir krize neden olur. Örneğin, lale soğanı ve kripto para 
yükselişleri davranışsal iktisatta sürü psikolojisine örnek teşkil etmektedir. Burada, yolsuzluk güdüsünde bahsedilen, piyasanın bize gerçekten istediklerimizin yanında istediğimizi sandığımız şeyleri de satmasından (eğer ki bir lale soğanının bir ev fiyatında olmasını istiyorsak piyasa bize bunu sağlayacaktır) kaynaklanan durum söz konusudur. Örneğin, 1980'lerde petrol fiyatları düştüğünde hikâyeler hükümsüz kalmıştır. Bu dönemde petrol fiyatlarının artmasında, petrolün tükenmesine dair hikâyelerin de etkili olduğu ifade edilmektedir. New York Times, Los Angeles Times ve Washington Post'ta petrolden bahseden makalelerin sayısı yıllar itibarıyla şu şekildedir: 1965-1969 yılları arasında 18 makale; 1970-1974 yılları arasında 60 makale; 1975-1979 yılları arasında 115 makale; 19801984 yılları arasında 137 makale ve son olarak 1985-1990 yılları arasında 73 makaledir.

Kitapta verilen başka bir örnek de, Toyota ve Nissan (Japonya) ile IKA (Arjantin) otomobil üreticileri karşılaştırılırken, güven ve adalet algılarının Toyota ve Nissan'ın başarılı olmasında, IKA'nın ise başarısız olmasında nasıl etkili olduğuna dairdir. Toyota ve Nissan'da işçi ile işveren arasında oluşturulan güven duygusu (burada, işçilere ömür boyu iş garantisi verilmesinin işçilerin firmayı sahiplenmesinde çok önemli rolü bulunmaktadır) nedeniyle, işçiler oluşan sorunları doğrudan adalet güdüsüne bağlamamaktadır. Fakat IKA'da işçi ile işveren arasında dönem itibarıyla çok güçlü bir çatışma mevcuttur. Öyle ki, bir gün IKA'nın işçileri ücretsiz izne çıkarmasıyla, işçiler firma yöneticilerini rehin almış ve durumu çözmek için devlet orduyu göreve çağırmıştır. IKA'nın iflas etmesinde işçi ile işveren arasındaki güven ve adalet duygusunun önemli bir payı bulunmaktadır.

Son olarak, gözlemler göstermiştir ki, güven kaybı nedeniyle borsalar düşerken yatırımlar da düşmektedir. Fakat enflasyon nedeniyle borsalar düşerken ekonomi gücünü koruyorsa yatırımlar düşmemektedir. Ekonomi için güven ortamının ne kadar önemli olduğu açıkça görülmektedir.

\subsection{Gayrimenkul Piyasalarındaki Konjonktürel Dalgalanmalar Niçin Yaşanır?}

Gayrimenkul fiyatlarındaki artışlar çoğunlukla nüfusu karşılayacak kadar arsa kalmadığı ve fiyatların hep yükseleceği hikâyelerine dayanmaktadır. Yatırımcılar bir daha mevcut fiyatlardan gayrimenkul bulamayacaklarına inanmaları halinde, fiyatlar ne kadar yükselmiş olsa da satın almaya devam etmektedirler. Bunun yanı sıra, para yanılsaması yine burada önemli bir etkendir. Örneğin, gayrimenkul, arsa ve araziler çok az değerlenen varlıklar olmasına rağmen geçen yıllarda alınan gayrimenkullerin şu anda değerlendirilmesi yapılırken enflasyon hesaba katılmadan yapılmakta ve ne kadar çok kâr edildiği düşünülmektedir. Örneğin, ABD’de reel konut fiyatları yüzyılda \%24 artış göstermiştir. İnsanların piyasadan beklentileri gayrimenkul fiyatlarının hep artış göstereceği yönünde olursa piyasa bu beklentiyi gerçekleştirecektir. Tabii ki bu fiyat yükselişi, piyasaya olan güvenin, sınırları aştı̆̆ı yere kadar olmaktadır. Diğer yandan, politikacıların siyasi nedenlerle 
aldıkları kararlar da dalgalanmalara neden olabilmektedir. Adalet alg1sı nedeniyle, gelir durumu düşük kimselerin de ev sahibi olması düşüncesiyle alınan kararlarla, bireylerin kredi notuna bakılmaksızın verilen krediler krize neden olabilmektedir.

\subsection{Yoksulluk Mağdur Azınlıklar Arasında Niçin Kuşaklar Boyunca Devam Eder?}

Azınlıkların maruz kaldıkları adaletsizliklerin yanı sıra kendilerine olan bakış açılarının da yoksulluğun sürekliliği üzerinde etkisi olduğu ifade edilmektedir. Bireylerin kendini toplum içinde mağdur görme alışkanlıkları, kendilerini gerçekleştirmelerinin önündeki en büyük engeli oluşturmaktadır. Ne olursa olsun bir şeyin değişmeyeceği algısı yoksulluk sarmalına yol açmaktadır.

Yapılan bir deneyde, insanların, tek ve çift rakamlı doğum günlerine göre ayrıldıktan sonra tekrar bir araya geldiklerinde, birbirlerine karşı bir önyargı taşıdıkları görülmüştür. $\mathrm{Bu}$ kadar basit bir nedenden dolayı insanların ayrışabilmesi, toplumdaki çok daha önemli konularda ayrışmanın daha kolay olacağı sonucunu vermektedir. Azınlıkların ayrıştırılması ve haksızlığa uğraması önemli bir sorundur. Kitapta ABD için verilen örnekte, bir yanda siyahi başkanın, valilerin ve başsavcıların, diğer yanda 800.000 hükümlünün bulunması, çözülmesi gereken bir soruna işaret etmektedir. Bu durum, akvaryumdaki balık örneğinde olduğu gibi öğrenilmiş çaresizliğe benzemektedir. Adalet algısı burada önemli bir rol oynamaktadır.

\section{Genel Değerlendirme}

$\mathrm{Bu}$ kitapta, geleneksel iktisat teorisinin varsayımları ve onun ekonomik olayları açıklamada kullandığı ekonometri ve istatistik temelli modeller eleştirilirken, yerine davranışsal iktisat teorisi koyulmaktadır. Gelenekten bir kopuş olarak görülen bu kitap, mevcut iktisat teorisinin yapamadığını yaparak ekonominin gerçekte nasıl işlediğini anlatmaktadır. Bunu da ekonomiye hayvansal güdüleri dahil ederek gerçekleştirmektedir. Çünkü geleneksel iktisatçılar makroekonomiyi bilimsel kılma çabasıyla, insanların yalnızca iktisadi güdüleriyle hareket ettiklerinde ekonominin nasıl davranacağına odaklanan bir disiplin dayatmışlardır.

Hayvansal güdülerin olmadığı mevcut iktisadi model, sadece "insanlar yalnızca iktisadi güdülerle hareket etse ve rasyonel tepkiler verseydi ekonomi nasıl davranırdı?" sorusuna cevap vermektedir. Geriye kalan şu sorulara ise cevap verememektedir: İktisadi olmayan güdüler ve rasyonel tepkiler söz konusu olsaydı ekonomi nasıl davranırdı? İktisadi güdüler ve rasyonel olmayan tepkiler gelişmesi durumunda ne olurdu? İktisadi olmayan güdüler ve rasyonel olmayan tepkiler var olduğunda ne olurdu? Bu noktalarda, devlet gerektiğinde 
ekonomiye müdahale etmelidir. Buradaki vizyon sadece makroekonomik geçmişleri açıkladığı için değil, kapitalist ekonomilerin işleyişini de açıkladığı için benimsenmelidir. Çünkü duygular sıcakken basit ekonomik doğrular gözden kaçabilmektedir.

Hakem Değerlendirmesi: Dış bağımsız.

Çıkar Çatışması: Yazar çıkar çatışması bildirmemiştir.

Finansal Destek: Yazar bu çalışma için finansal destek almadığını beyan etmiştir.

Peer-review: Externally peer-reviewed.

Conflict of Interest: The authos has no conflict of interest to declare.

Grant Support: The author declared that this study has received no financial support.

\section{Kaynakça/References}

Akkaya, Ş. (2011), Küreselleşen Ekonomik Sorunlar ve Vergilemenin Küreselleşmesi, İstanbul: Filiz Kitabevi.

Hazine ve Maliye Bakanlığı. (Erişim Tarihi: 2020). Vatandaş Bütçe Rehberi. https://www.hmb.gov.tr/bumkovatandas-butce-rehberi (Erişim Tarihi: 15.01.2020).

Thaler, H. R., (2019), Akıllı İnsanların Mantıksız Kararları (1.bs), (Zafer Akın, Çev.), İstanbul: Pegasus Yayınları. 